\title{
GOVORNIŠTVO - POTREBA U HRVATSKOMU ODGOJNO-OBRAZOVNOMU SUSTAVU
}

\author{
Danijela Sunara-Jozek \\ Osnovna škola prof. Franje Viktora Šignjara Virje, Republika Hrvatska
}

\begin{abstract}
Sažetak
Razvoj tehnologije, s jedne strane, primorava ljude da više komuniciraju, a opet s druge strane ovisnost o računalima i društvenim mrežama ljude fizički udaljava, što mijenja komunikacijske obrasce. Tim su promjenama najviše podložni mladi. Svjedoci smo sve lošijega jezičnoga izražavanja naših osnovnoškolaca pri čemu su teškoće vidljive i u pisanomu i u usmenomu izražavanju (čitanju i govorenju). Cilj je ovoga rada istaknuti razliku između jezične i komunikacijske kompetencije, ukazati na značenje govorništva kao discipline $u$ antičkom razdoblju i danas te prikazati istraživanje o usmenomu izražavanju osnovnoškolaca u Hrvatskoj koje je anketno provedeno pomoću obrasca Google Drive. U anketi je sudjelovalo 438 učitelja osnovnih škola. Cilj istraživanja bio je pokazati da je u 21. stoljeću izuzetno važno uvođenje govorništva u osnovnoškolski odgojno-obrazovni sustav jer su rezultati ankete potvrdili prvu hipotezu da je usmeno izražavanje naših osnovnoškolaca osrednje.

Govorništvo je disciplina koja nikako nije zastarjela. U doba globalizacije, prožimanja kultura, migracija (fizičkih ili onih posredstvom različitih tehnologijskih dostignuća) te razvoja medija ona je sve više potrebna. Sve je češća praksa da se govorničke vještine usavršavaju tek kada pojedinac osjeti da mu je to nužno potrebno ili se one uopće ne usavršavaju, pa smo svjedoci mnogobrojnih govorničkih (ne) uspjeha.
\end{abstract}

Ključne riječi: govorništvo, jezična kompetencija, komunikacijska kompetencija, kurikul(um), osnovnoškolski odgoj i obrazovanje, usmeno izražavanje.

\section{UvoD}

Sadašnja podjela područja u okviru predmeta Hrvatski jezik u osnovnim školama jest jezik, književnost, lektira, usmeno izražavanje, pismeno izražavanje i medijska kultura. Jasno je da se u području usmeno izražavanje učenike podučava i vrednuje učenikova govornička vještina. Prema Nacionalnom kurikulumu predmeta Hrvatski jezik iz 2019. godine predlažu se sljedeća područja Hrvatskoga jezika: komunikacija i jezik, književnost i stvaralaštvo i kultura i mediji, a četiri osnovne vještine: slušanje, čitanje, pisanje i govorenje trebaju biti zastupljene u svim trima područjima. Smanjivanjem nastavnih područja te njihovim preimenovanjem ne rješava se problem loših govorničkih vještina naših učenika. Uza sve nastavne sadržaje koje učenici trebaju usvojiti iz predmeta Hrvatski jezik, nedovoljno vremena ostaje za vježbanje govorničkih vještina. Kada učenici izađu iz osnovnoškolskoga, ali i srednjoškolskoga odgojnoobrazovnoga sustava, najčešće nisu dovoljno kompetentni u govorničkim vještinama. Učenici koji su u tome nešto vještiji, više su nadareni ili govorničke vještine usavršavaju u nekim izvannastavnim ili izvanškolskim aktivnostima. Nekada je retorika bila temelj obrazovanja, a danas kada je sve više potrebna s obzirom na nova zanimanja i način života koji pretpostavlja sve bolje govorničke sposobnosti, posve je zanemarena.

Mnoga zanimanja pretpostavljaju što bolju govorničku vještinu (pravnici, učitelji, nastavnici, profesori, medijski djelatnici, menadžeri, političari, glasnogovornici), ali je ona potrebna i 
svima onima koji rade s ljudima. Činjenica je da ljudi više cijene one koji su vještiji u iznošenju svojih ideja i misli, koji s lakoćom iznose svoje mišljenje.

Manji su pomaci učinjeni samo u nekolicini srednjoškolskih odgojno-obrazovanih ustanova, i to uglavnom u privatnim gimnazijama.

\section{Jezična i komunikacijska kompetencija}

U 21. stoljeću riječ komunikacija jedna je od najčešće upotrijebljenih riječi. Nebrojeno se puta u literaturi, na internetu ili u svakodnevnoj komunikaciji iznose misli da je komunikacija jako važna za privatni i poslovni život, da se komunikacijske kompetencije sve više cijene pri zapošljavanju, sve je više zanimanja u kojima se koristimo komunikacijskim kompetencijama, komunikacija je sastavni dio profesionalne karijere gotovo svakoga i tako dalje. Postavlja se pitanje kako naš odgojno-obrazovni sustav priprema naše učenike za sve komunikacijske izazove.

Nastavni planovi i programi Hrvatskoga jezika prepuni su jezičnih sadržaja, ali to nije dovoljno za komunikacijsku kompetenciju. „Jezična se sposobnost provjeravala stupnjem usvojenosti gramatičko-pravopisnih pravila dok su komunikacijske vještine, osobito vještine govorenja i slušanja, bile zanemarene jer se na njih gledalo kao na čovjekove biološki dane sposobnosti" (Bakota, 2010, str. 10). Ono što je mladim naraštajima važno za novonastalo tržište rada jest komunikacijska kompetencija.

„Za razliku od jezične kompetencije, komunikacijska kompetencija pokazuje ne samo poznavanje struktura jezika već i načela uporabe tih struktura u različitim društveno-kulturnim aktivnostima, gdje se mogu manifestirati i različiti jezični varijeteti. Prema tome, komunikacijska kompetencija podrazumijeva posjedovanje gramatičke kompetencije i sociolingvističkih pravila uporabe te gramatike" (Vrhovac, 200, str. 16).

Sadašnjim nastavnim planovima i programima te načinom rada u osnovnim školama naši učenici usavršavaju jezičnu kompetenciju i ponekad je ona vrlo dobra, ali komunikacijska kompetencija kod većine nije dovoljno razvijena. Često će se čuti od učitelja hrvatskoga jezika rečenica: „Pravilo bez pogreške izgovori, ali ga ne primjenjuje." Velik dio onoga što učenici usvoje kao pravila, npr. da aorist pomoćnoga glagola biti glasi: ja bih, ti bi, on, ona, ono bi, mi bismo, vi biste, oni bi, ne primjenjuju u pisanomu ili usmenomu izražavanju. Nauče da sastavak treba imati uvod, razradu i zaključak, ali ne ostvare to prilikom pisanja toga teksta. Potrebno je vlastitu jezičnu kompetenciju primijeniti u stvarnomu komunikacijskomu okružju. Ono što je još važno jest činjenica da kompetencije mogu biti urođene, a važne su vještine koje se stječu, odnosno naš bi odgojno-obrazovni sustav trebao razvijati komunikacijske vještine. Mnoge se komunikacijske vještine stječu učenjem i uvježbavanjem (na primjer, znati što i kako reći u određenim situacijama, stvarati društveno prihvatljive iskaze, razvijati kulturu govorenja, znati kada treba dati i/ili preuzeti riječ i sl.) (Bakota, 2010).

Najjednostavnije rečeno, jezična je kompetencija urođena, a komunikacijsku kompetenciju treba razvijati.

Nastavni plan i program Hrvatskoga jezika ne zanemaruje komunikacijske kompetencije, ali nije dovoljno ono što se njime nudi. Previše je nastavnih sadržaja koje treba obraditi i na taj način raditi na jezičnoj kompetenciji, a nedovoljno je prostora, čak i za one snalažljivije, da rade s učenicima na način da oni slušaju govore, pripremaju ih, izvode ih i analiziraju.

„Budući da je jedno od nastavnih područja hrvatskog jezika jezično izražavanje, koje obuhvaća i govorenje, jedan od glavnih zadataka nastave hrvatskog jezika je da učenikovo znanje nadogradi i unaprijedi kako bi se on mogao uspješno sporazumijevati, kako u svojoj okolini tako i u svim funkcionalnim stilovima književnog standard."

(http://sreckolistes.com/dokumenti_skola/dokumenti_pripravnici/pisani_rad_primjer_4.pdf). 


\section{Antička retorika}

Retorika danas doživljava novi procvat. Valja reći da živimo u komunikacijskome društvu u kojemu se pojedinci izražavaju, raspravljaju, nastoje se svidjeti, zavesti i uvjeriti (Meyer, Carrilho i Timmermans, 2008). No, opet se to događa u zapadnjačkim kulturama gdje su davno prepoznali bogatstvo i značenje govorničkih vještina. Sve najvažnije o retorici rečeno je davno. Antički retoričari dali su nam sve osnovne spoznaje o retorici kao umijeću lijepoga govorenja ili umijeću uvjeravanja. Aristotel retoriku opisuje kao sposobnost uočavanja bitnoga i primarnoga svojstva kojim se može uvjeriti, a koje u sebi krije svaki predmet ili pojava (Aristotel, 1989). Retorika je vještina uvjeravanja te je iznimno važna riječ vještina, što znači da se treba uvježbavati. Kvintilijanova uzrečica Pjesnikom se rađa, govornikom se postaje nebrojeno je puta ponavljanja, izgovorena i napisana, ali nikada dovoljno ozbiljno shvaćena. Postati ne znači postati čarobnim štapićem, već proučavanjem, vježbanjem i radom na svojim govorničkim sposobnostima. lako je u antičko doba bilo mnogo manje zanimanja koja su se temeljila na govorničkim sposobnostima, pridavali su joj veliko značenje. Političari su bili cijenjeni upravo po govorničkim sposobnostima (bilo bi dobro da je i danas tako!). Ciceron, Platon, Aristotel, Koraks, Protagora, Izokrat i mnogi drugi cijenili su govorništvo i neprestano se usavršavali u govorničkim vještinama, iako se u to doba razlikovala sofistička retorika kojoj je svrha bila uvjeravati bez obzira na cilj (makar i negativan), dok je drugoj vrsti retorike bila istina kao ideal (Kišiček, 2018). Važnu ulogu retorike $u$ antičkome društvu potvrđuje i njezin status kao predmeta, uz glazbu, matematiku, gramatiku i umjetnost.

\section{Retorika u hrvatskom osnovnoškolskom odgoju i obrazovanju}

Retorika je disciplina koja uči i kako razmišljati, kako logički povezivati i zaključivati, kako biti kreativan i originalan u osmišljavanju ideja (Kišiček i Stanković, 2014). To je misao koja nam treba reći koliko je retorika važna za naše učenike. Osim samoga pripremanja govora i njegova izvođenja, učeći retoriku učenici će razvijati i usavršavati sve one kognitivne procese koji su važni za bilo koji predmet, zanimanje, posao, ali i za osobni razvoj pojedinca.

„Ako naše školstvo želi mladež cjelovito pripraviti za ovaj naš svijet i usmjeriti mu svijest prema njemu, onda kolebanja oko uvođenja retorike u škole ne može biti. Kolebati se može o količini te nastave i o načinima izvedbe, pa i o nazivu predmeta, koji se može nazvati retorika, oratorstvo, govorništvo, govorna kultura, govorno izražavanje, govorna komunikacija ili kako drukčije" (Škarić, 2000: 12).

U našemu se osnovnoškolskomu obrazovanju prednost daje jezičnim i književnim teorijama, a onda koliko vremena ostane posvećuje se usmenom i pisanom usavršavanju.

Prema Stipinović „jedan od glavnih zadataka nastave Hrvatskog jezika je da učenikovo znanje nadogradi i unaprijedi kako bi se on mogao uspješno sporazumijevati, kako u svojoj okolini tako i u svim funkcionalnim stilovima književnog standarda“. (http://www.sreckolistes. com/dokumenti_skola/dokumenti_pripravnici/pisani_rad_primjer_4.pdf) Usmeno izražavanje zahtjevno je područje koje kod učenika pretpostavlja osvješćivanje da mu je potrebno poznavanje jezika koje tada treba primijeniti. S druge strane, učenik treba ovladati svojim glasom (vježbe za glas i izgovor), tremom koju bi trebalo svesti na minimum, ali i nečime što se često zaboravlja - slušanjem sebe i drugih. To je niz složenih zahtjeva koje je teško provoditi samo u sklopu predmeta Hrvatski jezik i zato bi zaseban predmet bio mnogo bolje i učinkovitije rješenje.

Govorništvo postoji i vrednuje se, ali nije dobar način njegova podučavanja. Tako usputno i nesustavno kako se to danas radi, neće donijeti velike promjene u usmenomu izražavanju i govornomu usavršavanju naših učenika.

„Kultura komunikacije u javnom diskursu prvi je i najjasniji pokazatelj kulture društva općenito“ (Kišiček, 2018, str. 120). Danas se pojam javnoga proširio i sve je postalo javno. Digi- 
talizacija, sveprisutnost medija i života u tzv. „globalnom selu“ dovela je do toga da je komunikacija jako važna, a učenike itekako trebamo pripremati za život.

Neke su škole prepoznale važnost govorništva i uvele su ga kao izvannastavnu aktivnost ili kao izborni predmet, npr. u Gimnaziji Frana Galovića u Koprivnici. Profesorica hrvatskoga jezika, koja je u toj školi predavačica Govorništva, napisala je u Pogledu kroz prozor sljedeće: „Svrha predmeta Govorništvo je obogaćivanje srednjoškolske nastave hrvatskog jezika razvijanjem komunikacijskih vještina. Sve više postajemo svjesni kako je komunikacijska kompetencija jedna od temeljnih kompetencija u razvoju modernog, obrazovanog i uspješnog čovjeka. Na svim razinama suvremeno demokratsko društvo traži upravo takve vještine - i ta je činjenica bila temeljni poticaj za osmišljavanje ovog programa“ (Novosel, 2010).

Prema promjenama u Nacionalnom kurikulumu za predmet Hrvatski jezik ne vidi se da će sada biti više prostora za rad s učenicima na tom području jer je satnica Hrvatskoga jezika ostala jednaka, a opseg sadržaja nije se smanjio. Učiteljima je samo dana veća sloboda u odabiru tekstova (suvremeniji književni tekstovi, neknjiževni tekstovi) pri obradi, ponavljanju ili vježbanju jezičnih i književnih sadržaja. Naglasak se stavlja na razvijanje vještina govorenja, čitanja, pisanja i slušanja, ali opet pored svih nastavnih sadržaja kojima treba učenike podučavati, neće biti dovoljno vremena za usavršavanje govorničkih vještina. Ono što će neki učitelji učiniti jest da će u nekom razdoblju možda tematski planirati razvijanje govorničkih vještina (što im dopušta novi Kurikulum), ali to neće činiti svi u Republici Hrvatskoj i na taj način opet nemamo sustavno razvijanje te vještine.

U Nacionalnom kurikulumu za predmet Hrvatski jezik nastavno područje komunikacija i jezik trebalo bi biti područje u kojem bi se posebna pozornost dala upravo govorništvu. U Kurikulumu se to područje objašnjava ovako: „Predmetno područje hrvatski jezik i komunikacija temelji se na ovladavanju uporabnim mogućnostima hrvatskoga jezika u jezičnim djelatnostima slušanja, govorenja, čitanja, pisanja i međudjelovanja koje omogućuju stjecanje komunikacijske jezične kompetencije na hrvatskome standardnom jeziku. Predmetno područje obuhvaća stjecanje:

- jezične, uporabne, strategijske i društveno-jezične kompetencije

- vještina komunikacije i suradnje s drugima u različitim kontekstima, medijima i komunikacijskim situacijama

- komunikacijskih strategija radi razumijevanja i stvaranja teksta na temelju prije stečenoga znanja i učenja

- sposobnosti pomnoga čitanja obavijesnih i književnih tekstova, sposobnosti analize i interpretacije teksta te razumijevanja konteksta i značenjskih slojeva

- kompetencije stvaranja tekstova različitih vrsta i funkcionalnih stilova

- svijesti o sebi kao osobi koja izgrađuje, poštuje i izražava vlastiti (jezični) identitet te poštuje identitet drugih u okviru jezične i kulturno-jezične govorne zajednice" (Nacionalni kurikulum nastavnoga predmeta Hrvatski jezik, 2019, str. 4 ).

Protivnici uvođenja još jednoga predmeta sigurno bi rekli da bi to samo opteretilo učenike, ali s obzirom na mogućnost izvrsnoga koreliranja govorništva sa svim obveznim i izbornim predmetima, to bi učenicima donijelo samo pozitivne pomake.

Zaseban predmet Govorništvo uvelike podupire i mnoge druge predmete i nije dodatno opterećenje učenicima, nego samo velika pomoć i korist, što se očituje i u Aristotelovom poimanju govorništva kao discipline koja razlikuje bitno od nebitnoga, što je važno za informacijsku pismenost koja se, prema novom Kurikulumu, također smatra iznimno važnom pismenošću u današnjem društvu. „Govorništvo je povezano i s ostalim predmetima jer se oslanja na određena znanja iz područja povijesti, logike, filozofije, etike, vjeronauka, psihologije. Saznanja i sadržaji koje učenici usvoje na satovima govorništva pomažu im i u ostalim predmetima u smislu boljeg snalaženja u koncipiranju različitih govorničkih oblika, primjerice izlaganja, referata, 
Danijela Sunara-Jozek

rasprava. Sve im to omogućava bolje svladavanje gradiva i bolju prezentaciju znanja“ (Novosel, 2010).

Osim spomenute koprivničke gimnazije još su neke škole uočile veliku potrebu za govorništvom te su ga uvele kao predmet. Nažalost, sve su to srednje škole, i to uglavnom privatne gimnazije (XVIII. gimnazija Zagreb, Privatna jezično-informatička gimnazija Svijet, Opća privatna gimnazija Zagreb, Privatna gimnazija Varaždin, Prva privatna gimnazija Zagreb, Klasična gimnazija Zagreb, Zagrebačka umjetnička gimnazija, Privatna umjetnička gimnazija Zagreb, Privatna gimnazija i ekonomsko-informatička škola Futura i Klasična gimnazija Ivana Pavla II. Zadar). Jedina osnovna škola koja provodi nastavu govorništva jest OŠ Ludina. Govorništvo bi se trebalo uvesti i u osnovne škole kako bi se planirano i sustavno podučavalo učenike one sadržaje iz govorništva koji su primjereni njihovu psihičkom i intelektualnom razvoju.

„Kako bi naučili učenike nositi se s pojavom straha kod usmenog ispitivanja te o načinima komuniciranja s učiteljima i ostalima u nastavnom procesu, u našoj je školi pokrenuta izvannastavna aktivnost Govorništvo. lako živimo u doba tehnoloških čuda čijim kanalima svakodnevno komuniciramo, govor i ljudski kontakt ne možemo i ne smijemo zanemariti. Učenike trebamo poticati da budu bolji govornici i uspješniji sugovornici u nastavnom procesu, a to mogu samo ako znaju slušati. No, svjesni smo da je danas komunikaciju u učionici teško održavati, zar ne?" (Mihelčić, 2017). U Sloveniji postoji govorništvo kao obvezni izborni predmet u 9. razredu, dok se u Srbiji uvodi u 4. razredu gimnazije.

U Republici Hrvatskoj je paradoksalno to što se generacijama školuju profesori fonetike na Filozofskome fakultetu u Zagrebu koji potom ostaju nezaposleni ili se zapošljavaju zahvaljujući tome što su uz fonetiku studirali još jedan studijski program (kroatistiku, pedagogiju, sociologiju, neki strani jezik i sl.), a znanje fonetičara ostaje neiskorišteno.

O potrebi uvođenja govorništva u odgojno-obrazovni sustav mnogo je govorio autor najpoznatijih knjiga o govorništvu u Hrvatskoj Ivo Škarić (Barbir, 2014). Do 2012. godine održavala se Govornička škola koja je funkcionirala kao tečaj govorništva za srednjoškolce u trajanju od 9 dana u organizaciji Odjela za fonetiku Hrvatskoga filološkoga društva, Nažalost, zbog organizacijskih teškoća Škola se ne održava već sedam godina.

\section{Metoda}

Cilj provedenog istraživanja bio je utvrditi sumativnu ocjenu usmenoga izražavanja učenika osnovnih škola te istražiti rade li učitelji u hrvatskim školama na poboljšanju usmenoga izražavanja učenika u okviru svojega predmeta i kojim metodama.

Iz tih ciljeva proizlaze sljedeća dva problema:

1. Ispitati učiteljsku procjenu razine usmenoga izražavanja hrvatskih osnovnoškolaca.

2. Ispitati postoji li potreba za uvođenjem govorništva kao predmeta u osnovnoškolski odgojno-obrazovni sustav u Republici Hrvatskoj.

S obzirom na dosadašnje teorijske spoznaje postavljene su sljedeće hipoteze:

H1: Učitelji osnovnih škola Republike Hrvatske usmeno izražavanje hrvatskih osnovnoškolaca ocjenjuju prosječnom ocjenom.

H2: U osnovnoškolski odgojno-obrazovni sustav treba uvesti govorništvo kao predmet. 


\section{Sudionici istraživanja}

Sudionici su istraživanja učitelji osnovnih škola razredne i predmetne nastave OŠ Gola, OŠ Grgura Karlovčana iz Đurđevca i OŠ prof. Franje Viktora Šignjara iz Virja te učitelji na Facebookovoj grupi Nastavnici.org. Sveukupno je sudjelovalo 438 ispitanika.

\section{Mjerni instrumenti}

Istraživanje je provedeno anketno aplikacijom Google Drive, koja je poslana na elektroničke adrese triju navedenih osnovnih škola te u Facebookovu grupu Nastavnici.org. Anketa se sastojala od dvaju pitanja na koja je trebalo odgovoriti potvrdno ili niječno (da - ne). Ispitanici su trebali označili kojom bi ocjenom vrednovali usmeno izražavanje svojih učenika (ponuđene su bile sljedeće ocjene: nedovoljan (1), dovoljan (2), dobar (3), vrlo dobar (4) i odličan (5)). Jedan od zadataka bio je višestrukoga izbora, tj. ispitanici su trebali označiti kojim se metodama koriste kako bi unaprijedili usmeno izražavanje učenika, a mogli su dodati i neke metode koje nisu bile navedene.

\section{Postupak istraživanja}

Anonimno anketno ispitivanje provedeno je tijekom veljače 2019. godine i ispitivanju su pristupili oni učitelji koji su to htjeli, a postupak ispunjavanja ankete trajao je oko 4 minute.

\section{ReZULtATI}

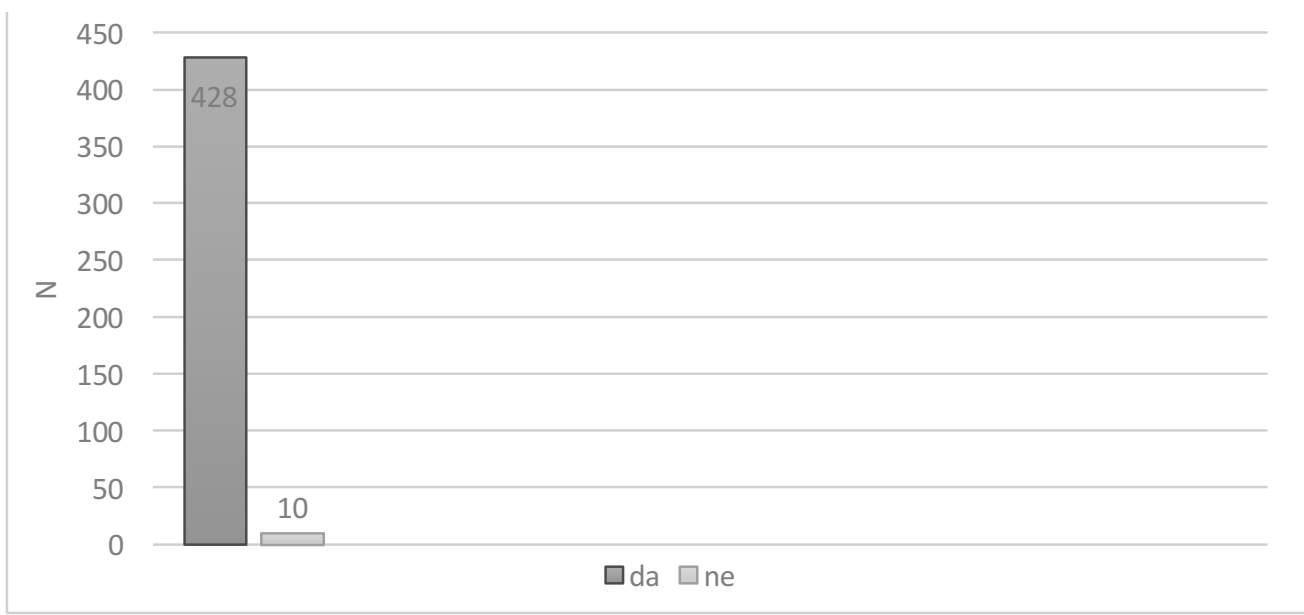

Grafikon 1. Rezultati anketnoga pitanja Radite li sa svojim učenicima na poboljšanju njihova usmenoga izražavanja?

Prema rezultatima prikazanima na Grafikonu 1. vidi se da učitelji u osnovnim školama, ovisno o predmetu i mogućnostima, rade na usmenom izražavanju svojih učenika. Njih $97,7 \%$ označilo je odgovor da, što je 428 ispitanika od ukupno 438 anketiranih.

Sljedeći zadatak bio je označiti metodu kojom se koriste za razvijanje učeničkih govorničkih sposobnosti ili sami napisati ako se koriste nekom od metoda koja nije bila navedena među ponuđenima. Rezultati su bili sljedeći: 
Danijela Sunara-Jozek GOVORNIŠTVO - POTREBA U HRVATSKOMU

Tablica 1. Rezultati u broju i postotcima korištenja nastavnim metodama za uvježbavanje govorničkih sposobnosti učenika

\begin{tabular}{|l|c|c|}
\hline \multicolumn{1}{|c|}{ Metoda rada } & $\begin{array}{c}\text { Broj ispitanika koji se opredijelio } \\
\text { za određenu metodu }\end{array}$ & Postotak \\
\hline razgovor & 389 & $88,8 \%$ \\
\hline komentiranje nakon čitanja, gledanja & 317 & $72,4 \%$ \\
\hline čitanje & 304 & $69,4 \%$ \\
\hline prepričavanje & 302 & $68,9 \%$ \\
\hline izlaganje & 279 & $63,7 \%$ \\
\hline scenske improvizacije & 183 & $41,8 \%$ \\
\hline krasnoslov & 116 & $26,5 \%$ \\
\hline izvođenje govora & 78 & $17,8 \%$ \\
\hline debata & 2 & $0,4 \%$ \\
\hline pripovijedanje prema poticaju & 1 & $0,2 \%$ \\
\hline objašnjavanje postupka (matematika) & 1 & $0,2 \%$ \\
\hline
\end{tabular}

Iz prikazanih rezultata vidljivo je da su razgovor, čitanje, prepričavanje i izlaganje najčešće nastavne metode, izvođenjem govora koristi se 78 ispitanika, dok se debatom u nastavi koristi tek dvoje ispitanika. Pripovijedanje prema poticaju naveo je jedan ispitanik kao i objašnjavanje postupka. Razlozi su tome sljedeći: učitelji nemaju vremena za takve nastavne sadržaje jer ima previše obveznih sadržaja koje treba obraditi, ponoviti, uvježbati i provjeriti. Naravno, nisu svi predmeti prikladni za poseban rad na govorničkim vještinama, a treći je razlog što nisu svi učitelji kompetentni za podučavanje govorničkih vještina.

Tablica 2. Rezultati anketnoga pitanja o ocjeni koju bi dodijelili za govorne vještine svojih učenika

\begin{tabular}{|c|c|c|c|c|c|}
\hline ocjena & nedovoljan (1) & dovoljan (2) & dobar (3) & vrlo dobar (4) & odličan (5) \\
\hline N- 412 & 7 & 81 & 278 & 52 & 0 \\
\hline postotak & $2 \%$ & $19,4 \%$ & $66,5 \%$ & $12,4 \%$ & $0 \%$ \\
\hline
\end{tabular}

Rezultati pokazuju da nijedan ispitanik ne bi za govorno izražavanje svojih učenika dao ocjenu odličan (5). Taj rezultat u suprotnosti je s podatcima kako u hrvatskom osnovnoškolskom sustavu ima mnogo odlikaša. Ocjenom vrlo dobar (4) učeničke govorne vještine ocijenilo je $12,4 \%$ ispitanika. Prolaznu ocjenu dovoljan dobilo bi $19,4 \%$ učenika. Najviše učenika u Hrvatskoj iz usmenoga izražavanja dobilo bi ocjenu dobar (3), njih 66,5\%, a neki bi čak dobili i neprolaznu ocjenu nedovoljan (1). Na to pitanje nisu odgovorili svi ispitanici. Od ukupno 438 odgovorilo je 412 ispitanika.

Rezultati pokazuju da su govorničke sposobnosti učenika u osnovnim školama osrednje. 


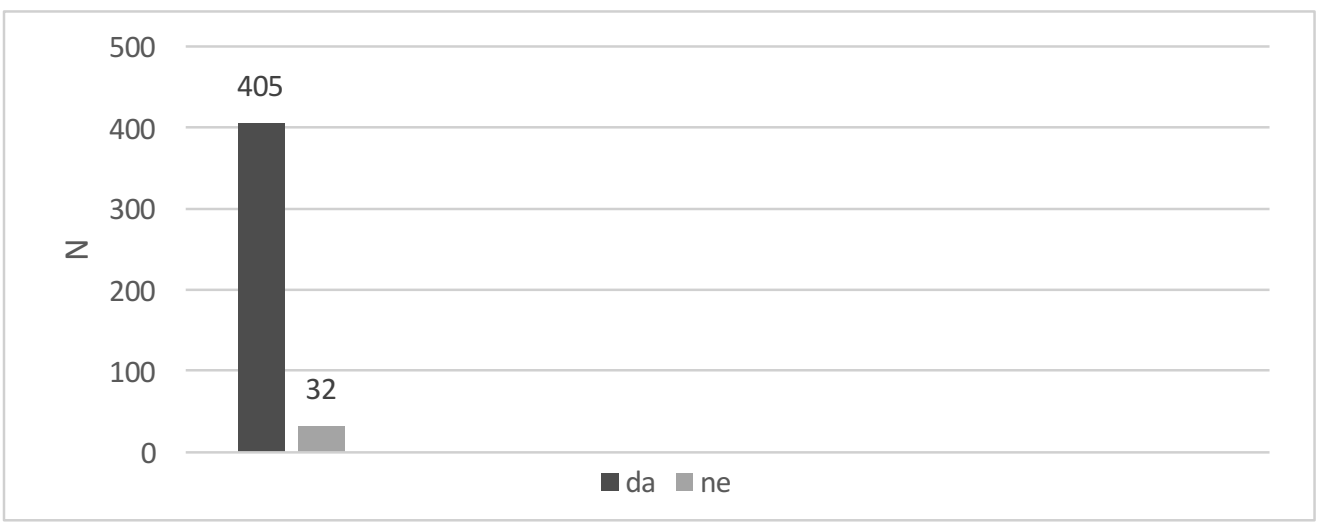

Grafikon 2. Rezultati anketnoga pitanja Smatrate li da bi nastava govorništva u odgojno-obrazovnom sustavu Republike Hrvatske bila korisna za naše učenike?

Vidljivo je da odgojno-obrazovni djelatnici u osnovnim školama smatraju govorništvo poželjnim predmetom. Uvođenje govorništva kao zasebnoga predmeta olakšalo bi mnogim predmetnim učiteljima podučavanje njihova predmeta jer bi se manje bavili govorničkim vještinama učenika. Učenici bi teme svojih izlaganja uzimali iz svih predmeta, najčešće prema vlastitim sklonostima, što bi učenicima također bila velika korist. Pripremajući se za izlaganje ili govor, istraživali bi različite izvore (tiskane i digitalne), razvijali informacijsku pismenost, usvajali informacije iz određenoga područja, primjenjivali gramatičke zakonitosti hrvatskoga jezika pišući tekst koji će kasnije usmeno predstaviti. Činjenica da bi učenici samostalno učili pridonosi individualizaciji kojoj se teži u suvremenim školskim sustavima. Učitelji bi bili oni koji bi usmjeravali učenike pri pripremanju izlaganja, a oni bi samostalno istraživali, pronalazili informacije, selektirali informacije, osmišljavali strukturu govora i pripremali se uz neprestano formativno vrednovanje učitelja.

Istraživanja pokazuju da je učenicima velik problem trema, a na satima govorništva upravo se toj problematici posvećuje dio sati. Dobrom pripremom i redovitim izvođenjem izlaganja i govora pred publikom, usavršili bi tu vještinu pa bi im javni nastup postao manje stresan.

\section{RASPRAVA}

Iz provedenoga istraživanja među učiteljima i nastavnicima u hrvatskim osnovnim školama vidljivo je da sadašnji oblik i način provođenja podučavanja usmenoga izražavanja ne donosi zadovoljavajuće rezultate. Nakon osmogodišnjega osnovnoškolskoga obrazovanja usmeno izražavanje učenika nije visoko ocijenjeno. Odgojno-obrazovni djelatnici pokušavaju raditi na govorničkim sposobnostima naših učenika, i to najčešće metodama prepričavanja, krasnoslovljenja, razgovora, čitanja, scenskih improvizacija, izlaganjima, komentiranja pročitanoga i odgledanoga, scenskim improvizacijama, govorima... Govore, a posebno debate, prakticira malen broj ispitanika. Broj onih koji se izjasnio da bi govorništvo bilo korisno, kada bi se uvelo u osnovnoškolski odgojno-obrazovni sustav, velik je. Čak 92,7 \% ispitanika smatra da bi nastava govorništva u hrvatskomu odgojno-obrazovnomu sustavu bila korisna. Razlog je tome što navedene metode kojima se učitelji služe na svojim satima ne donose izvrsne govorničke sposobnosti naših učenika. Vrlo je relevantan podatak da nijedan ispitanik nije dao ocjenu odličan za govornu vještinu svojih učenika. Nakon provedenoga istraživanja i analize dobivenih rezultata obje su hipoteze potvrđene. 


\section{ZAKUUČAK}

Govorništvo je iznimno cijenjena vještina, a premalo joj se pozornosti posvećuje u hrvatskomu odgojno-obrazovnomu sustavu. Previše je nastavnih sadržaja koje je teško kvalitetno odraditi u postojećoj satnici i zato bi trebalo uvesti govorništvo kao školski predmet kako bi se učenici usavršavali u toj vještini (Novosel, 2010). Mnogo je zanimanja u kojima je vještina govorenja potrebna, a mnogo je elemenata koje treba naučiti i usavršiti da bi netko bio dobar govornik i izlagač. Osim pronalaženja teme, prikupljanja informacija, sastavljanja govora (izlaganja), zapamćivanja i same izvedbe, potrebno je prevladati i strah koji je velik problem mnogima. Prevladati strah bit će najučinkovitije mnogobrojnim govorničkim pokušajima (praksom) (Škarić, 2000; Zadro, 2001; Novosel, 2010).

Antički govornici i mislioci ostavili su nam u nasljeđe izvrsne temelje za rad na govorničkim vještinama. Sadašnje komunikacijske potrebe i promjene koje su izazvane tehnologijskim dostignućima i promjena tržišta rada koje sve više zahtijeva elokventne osobe, nameću nam veći rad i angažman na govorničkim vještinama sadašnjih i budućih generacija.

Rezultati istraživanja u kojemu je sudjelovalo 438 učitelja hrvatskih osnovnih škola pokazuju da učitelji govorničke vještine naših učenika u najvećem broju ocjenjuju ocjenama dovoljan (2) i dobar (3), a nijedan od ispitanika nije dao ocjenu odličan (5). Čak 428 ispitanika od ukupno 438 , koliko ih je sudjelovalo u anketiranju, tvrde da u nastavi rade na usavršavanju usmenoga izražavanja učenika (i u razrednoj i u predmetnoj nastavi). Na pitanje o korisnosti uvođenja govorništva u osnovnoškolski odgojno-obrazovni sustav u Hrvatskoj njih 405 odgovorilo je potvrdno. Dobiveni rezultati daju odgovor na pitanje je li govorništvo potrebno u na hrvatskom obrazovnom sustavu.

Govorništvo je vještina kojom bi se itekako razvijala komunikacijska kompetencija naših učenika i bila bi izvrsna nadopuna jezičnoj kompetenciji koju učenici stječu sadašnjim nastavnim planovima i programima u svim nastavnim predmetima.

Neminovno je da se u naš odgojno-obrazovni sustav uvede govorništvo jer vještine koje se stječu unutar te discipline budućnost su školskoga sustava 21. stoljeća.

\section{LITERATURA}

Bakota, L. (2010). Komunikacijski model govornih vježbi i nastava jezičnoga izražavanja. Hrvatski, 8(1), 9-43.

Barbir, Jelena. 2014. Vrednovanje učenika u nastavi govorništva. Diplomski rad. Zagreb: Filozofski fakultet

Kišiček, G., Stanković, D. (2014). Retorika i društvo. Govor, 31(2), 147-150.

Kišiček, G. (2018). Politika i retorika. Zagreb : Naklada Jesenski i Turk.

Meyer, M., Carrilho, M. M., Timmermans, B. (2008). Povijest retorike od Grka do naših dana. Zagreb : Disput.

Mihelčić, S. (2017). Govorništvo kao izvannastavna aktivnost. Preuzeto s https://www.profil-klett. $\mathrm{hr} /$ govornistvo-kao-izvannastavna-aktivnost, 30.12.2018.

Nacionalni kurikulum nastavnoga predmeta Hrvatski jezik. (2019). Ministarstvo obrazovanja. Preuzeto s https://www.mvinfo.hr/file/articleAttachment/file/odluka-o-donosenju-kurikulumaza-nastavni-predmet-hrvatski-jezik-za-osnovne-skole-i-gimnazije-u-republici-hrvatskoj.pdf, 2.4.2019.

Novosel, L. (2010). Nastava izbornog predmeta Govorništvo u Gimnaziji „Fran Galović“ Koprivnica. Pogled kroz prozor. Digitalni časopis za obrazovne stručnjake. Preuzeto s https:// pogledkrozprozor.wordpress.com/2010/01/30/nastava-izbornog-predmeta-govornistvo-ugimnaziji-\%e2\%80\%9efran-galovic\%e2\%80\%9c-koprivnica/, 29.12.2018. 
Stipinović, Sanja. Učenik - govornik u razvoju. Preuzeto s http://www.sreckolistes.com/dokumenti_ skola/dokumenti_pripravnici/pisani_rad_primjer_4.pdf, 28.12.2018.

Škarić, I. (2000). Temeljci suvremenoga govorništva. Zagreb. Školska knjiga.

Vrhovac, Y. (2001). Govorna komunikacija i interakcija na satu stranog jezika. Zagreb: Ljevak.

\title{
Speaking - a Need in the Croatian Educational System
}

\begin{abstract}
Technological development, on the one hand, allows people to communicate more, and yet on the other hand computers and social networks dependency, physically separates people, which changes communication patterns. Young people are the ones who are subject of the changes mentioned before. We are witnessing deterioration in language expression of our primary school pupils, where difficulties are evident in both writing and oral expression (reading and speaking). The aim of this paper is to highlight the difference between language and communication competence, to point out the importance of oratory as a discipline in the ancient period and today, and to present a survey of oral expression of primary school pupils in Croatia which was done through the Google Drive Form. 438 primary school teachers were involved in the survey. The aim of the research was to show that in the 21st century it is extremely important to introduce oratory into the primary school educational system because the survey results confirmed the first hypothesis that the oral expression of our primary school pupils is mediocre. Oratory is a discipline that is by no means outdated. At this time of globalization, intertwining culture, migration (physical or through different technological achievements) and the development of media, this discipline is increasingly needed. More common practice is to improve oratory skills only when an individual feels he needs them or they are not perfected at all, so we are witness to numerous oratory (un)successes.
\end{abstract}

Keywords: oratory, language competence, communication competence, curriculum, primary school education, oral expression.

\section{Bedarf an Rhetorik im kroatischen Bildungs - und Erziehungssystem}

Zusammenfassung: Durch die stetige Entwicklung der Technologie sind die Menschen einerseits immer mehr auf Kommunikation angewiesen, andererseits werden sie durch Abhängigkeit von Computern und sozialen Netzwerken im wahren Leben immer mehr voneinander entfernt, was wiederum die Kommunikationsmuster beeinflusst. Vor allem junge Menschen sind von diesen Veränderungen betroffen. Wir sind Zeugen eines immer schlechteren sprachlichen Ausdrucks unserer Schüler, wobei sich die Schwierigkeiten im schriftlichen und mündlichen Ausdruck bemerkbar machen (Schreiben und Sprechen). Das Ziel dieser Arbeit ist es den Unterschied zwischen der Sprach- und Kommunikationskompetenz hervorzuheben, auf die Bedeutung der Rhetorik als Disziplin seit der Antike bis heute hinzuweisen und die Ergebnisse der Studie zum mündlichen Ausdruck von Primar- und Sekundarstufenschülern in Kroatien zu präsentieren. Die Umfrage wurde mittels Google Drive durchgeführt und 438 Lehrer der Primarstufe und Sekundarstufe I nahmen teil. Das Ziel der Untersuchung war zu beweisen, dass es im 21. Jahrhundert außerordentlich wichtig ist, Rhetorik in diese Schulstufen einzuführen, da die Ergebnisse die Anfangshypothese bestätigt haben, nämlich dass der mündliche Ausdruck unserer Schüler nur mittelmäßig ist.

Die Rhetorik ist keinesfalls eine veraltete Disziplin. Im Zeitalter der Globalisierung, des gegenseitigen Durchdringens der Kulturen, der Migration (im Raum oder mittels unterschiedlichen technologischer Leistungen) und der Entwicklung der Medien steigt der Bedarf daran. Immer öfter beginnen Individuen ihre Redekunst erst dann zu verbessern, wenn sie spüren, dass dies zur Notwendigkeit geworden ist, oder aber gibt es viele, die sie gar nicht erst weiterentwickeln, weshalb wir Zeugen zahlreicher rednerischer Misserfolge sind.

Schlüsselwörter: Rhetorik, Sprachkompetenz, kommunikative Kompetenz, Lehrplan, Bildung und Erziehung in der Grundschule, mündlicher Ausdruck 